\title{
PENGOLAHAN LIMBAH KULIT KOPI (Coffea $s p$ ) SECARA SEDERHANA UNTUK MENGGANTIKAN SEBAGIAN JAGUNG DAN PENGARUHNYA TERHADAP KUALITAS KARKAS AYAM PEDAGING
}

\author{
Yunita Garing, Z. Poli, F.J. Nangoy, P.R.R.I. Montong
}

\author{
Fakultas Peternakan Universitas Sam Ratulangi Manado, 95115
}

\begin{abstract}
ABSTRAK
Tujuan penelitian ini untuk mengetahui apakah kulit buah kopi sebagai pengganti jagung memberikan pengaruh terhadap bobot badan akhir, persentase karkas, dan bobot lemak abdomen ayam pedaging. Penelitian ini dilaksanakan kandang Fakultas Peternakan Universitas Sam Ratulangi selama 35 hari. Strain ayam yang digunakan dalam penelitian ini yaitu $\mathrm{CP}$ 707144 ekor DOC tanpa membedakan jenis kelamin (unsexed). Rancangan yang digunakan yaitu rancangan acak lengkap (RAL) pola faktorial 3x4 dengan 3 ulangan dimana setiap ulangan terdiri atas empat ekor ayam.Faktor A terdiri atas tiga macam perlakuan yaitu kulit kopi yang dijemur (A1), kulit kopi yang direndam (A2), kulit kopi yang direbus (A3). Sedangkan factor B yaitu level substitusi kulit kopi terhadap jagung dimana B0 (0\% kulit kopi dalam ransum), B1 (substitusi 25\% kulit kopi, B2 (subtitusi 50\% kulit kopi) dan B3 (substitusi $75 \%$ kulit kopi). Variabel yang diamati yaitu Bobot Badan Akhir, Persentase Bobot Karkas, Bobot Lemak Abdomen. Dari hasil analisis keragaman menunjukkan bahwa interaksi antara kulit kopi (A) jemur, rendam, rebus dan level substitusi B memberikan pengaruh tidak berbeda nyata $(\mathrm{P}>0,05)$ terhadap bobot badan akhir, persentase karkas dan bobot lemak abdomen. Hasil yang sama juga ditunjukan oleh metode pengolahan kulit kopi (A) yang artinya jemur, rendam, rebus
\end{abstract}

*Kosepondensi(corresponding author) Email: richard_montong@unsrat.ac.id memberikan pengaruh yang tidak berbedanyata $(\mathrm{P}>0,05)$. Sedangkan hasil yang berbeda ditunjukan level substitusi B memberikan pengaruh berbeda sangat nyata $(\mathrm{P}<0.01)$ terhadap bobot badan akhir, persentase karkas, dan bobot lemak abdomen. Berdasarkan hasil penelitian dapat disimpulkan bahwa penggunaan kulit kopi dapat menurunkan lemak abdomen dan meningkatkan persentase karkas ayam pedaging. Kulit kopi dapat menggantikan jagung dengan level terbaik pada $25 \%$ $75 \%$.

Kata kunci: Limbah kulit kopi, jagung, kualitas karkas broiler

\section{ABSTRACT}

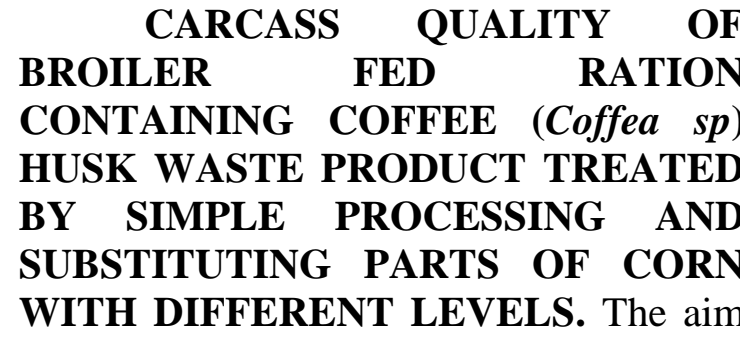
of this research was to know coffee husk waste product treated by simple processing and substituting parts of corn on body weight, carcass percentage and weight of abdominal fat Study was applied at Faculty of Animal Science, Sam Ratulangi University during 35 days. Total of 144 day old chick unsexed broilers, strain of CP 707, involving 36 experimental units of battery pens were used in this study. Each unit of pen was filled 4 birds under completely randomized design on factorial patter of $3 \times 4$. Factor $A$ was focused on three processing treatments including coffee husk 
heated under sun light (A1), coffee husk immersed in the water (A2), and coffee husk boiled under water (A3). Factor B was focused on four treatments of substitution levels including ration containing corn without coffee husk substitution (B0), ration containing corn substituted with $25 \%$ coffee husk (B1), ration containing corn substituted with $50 \%$ coffee husk (B2), ration containing corn substituted with $75 \%$ coffee husk (B3). Variables observed were including final body weight, carcass weight percentage and abdominal fat weight. Analysis of variance showed that interaction of processing treatments did not affect significantly on final body weight, carcass weight percentage and abdominal fat weight. This study showed that utilization of coffee husk waste product by above simple processing could substitute part of corn in ration of $25 \%-75 \%$ producing high carcass quality of broiler.

Key word: Coffee husk by product, corn, broiler carcass percentage

\section{PENDAHULUAN}

Produktivitas ayam pedaging diatur untuk mendapatkan daging berkualitas dengan kandungan nutrisi yang baik. Kualitas daging ayam dengan bobot karkas tinggi dan rendah lemak biasanyadapat menarik perhatian masyarakat untuk mengkonsumsi ayam pedaging. Kualitas karkas ayam pedaging yang dihasilkan sangat bergantung pada kebutuhan nutrisi (Widyaniet al., 2001). Kebutuhan nutrisi ayam pedaging memerlukan ransum yang seimbang antara kandungan protein, energi, vitamin dan mineral. Semakin baik ransum yang diberikan pada ayam maka akan menghasilkan bobot hidup yang tinggi (Wijaya, 2010). Jagung merupakan sumber energi sekaligus sumber ransum utama bagi ternak dengan tingkat penggunaan yang sangat tinggi karena memiliki kandungan energi metabolis yaitu $3182 \mathrm{kcal} / \mathrm{kg}$. Penggunaan jagungdalam ransum unggas mencapai $\quad 50-70 \%$, sehingga mengakibatkan persaingan kebutuhan dengan manusia dan harga jagung pun menjadi mahal. Ketersediaan ransum tentunya harus didukung dengan biaya murah agar tidak merugikan peternak. Oleh sebab itu perlu upaya pemanfaatan alternatif lain seperti limbah untuk menggantikan jagung. Limbah yang cocok menjadi ransum adalah kulit kopi.

Kulit kopi dapat digunakan sebagai pengganti jagung karena memiliki kandungan energi metabolisme hampir sama dengan jagung. Kulit kopi adalah limbah yang banyak ditemukan di daerah Indonesia dan tidak bersaing dengan kebutuhan manusia serta harga terjangkau. Menurut Wiguna (2007) hasil analisis proksimat menunjukkan bahwa kulit kopi mengandungenergi (GE) sebanyak 4140 $\mathrm{kcal} / \mathrm{kg}$, protein kasar $10,47 \%$, lemak $0,26 \%$, serat kasar $32,26 \%$. Kulit kopi sebagai ransum berserat kasar tinggi dapat dimanfaatkan untuk mencegah penimbunan lemak yang berlebihan pada ayam pedaging, agar menghasilkan kualitas karkas terbaik. Kualitas karkas yang baik 
diukur dengan bobot badan akhir, persentase karkas dan lemak abdomen. Semakin tinggi bobot badan akhir semakin baik pertumbuhannya sedangkan persentase karkas adalah besarnya persentase karkas (Ready to cook) dari bobot hidupnya. Tinggi rendahnya kualitas karkas ditentukan dari jumlah penimbunan lemak abdomen yang terdapat pada ayam tersebut semakin tinggi lemak abdomen semakin rendah kualitas karkas (Yuniastuti, 2002).

Berdasarkan uraian di atas, maka telah dilakukan penelitian untuk melihat sejauh mana pengaruh penggantian sebagian jagung dalam ransum ayam pedaging dengan limbah kulit kopi yang sudah diolah dengan menggunakan metode sederhana terhadap kualitaskarkas.

\section{MATERI DAN METODE PENELITIAN}

\section{Waktu dan Tempat Penelitian}

Penelitian ini dilaksanakan pada bulan Agustus-Oktober 2018 selama 35 hari dikandang Fakultas Peternakan Universitas Sam Ratulangi Manado.

\section{Materi penelitian}

Penelitian ini menggunakan strain CP 707 dari PT. Chaeron Phokphand sebanyak 144 ekor DOC (day old chicken) tanpa membedakan jenis kelamin (unsexed).
Bahan penyusun ransum yang digunakan dalam penelitianyaitu kulit kopi yang telah diolah dengan metode sederhana (dijemur, rendam dan rebus), jagung, dedak, konsentrat dan mineral. Komposisi zat nutrient bahan penyusun ransum perlakuan dapat dilihat pada Tabel 1, susunan bahan penyusun ransum perlakuan pada Tabel 2 dan komposisi zat nutrient ransum perlakuan dapat dilihat pada Tabel 3.

\section{Metode Penelitian}

Penelitian menggunakan rancangan acak lengkap (RAL) pola faktorial 3 x 4 (Steel and Torrie, 1980) 3 ulangan, dimana faktor A1 adalah kulit kopi yang dijemur, A2 direndam dan A3 direbus sedangkan Faktor B adalah 4 level substitusi kulit kopi terhadap jagung $\mathrm{B} 0=0 \%, \quad \mathrm{~B} 1=25 \%$, $\mathrm{B} 2=50 \%, \mathrm{~B} 3=75 \%$. Pemberian ransum komersial (AD1) pada ayam umur 1-14 hari, sebelum diberi ransum perlakuan secara menyeluruh dilakukan pra penyesuaian (preliminary. Ransum perlakuan diberikan kepada ayam umur 1535 hari. Data dianalisis dengan Anova (analysis of variance). Apabila perlakuan berpengaruh nyata, akan dilanjutkan dengan uji Beda Nyata Jujur (BNJ).

\section{Prosedur Pemotongan}

$$
\text { Pada akhir penelitian ayam }
$$
dipuasakan selama dua belas jam sebelum 
Tabel 1. Komposisi Zat Nutrien Bahan Penyusun Perlakuan

\begin{tabular}{lcccccc}
\hline Bahan pakan & $\begin{array}{c}\text { Protein } \\
(\%)\end{array}$ & $\begin{array}{c}\text { EM } \\
\mathrm{Kcal} / \mathrm{kg}\end{array}$ & $\begin{array}{c}\text { SK } \\
(\%)\end{array}$ & $\begin{array}{c}\text { Lemak } \\
(\%)\end{array}$ & $\begin{array}{c}\text { Ca } \\
(\%)\end{array}$ & $\begin{array}{c}\mathrm{P} \\
(\%)\end{array}$ \\
\hline Kulit kopi jemur* & 7,95 & 2895 & 33,6 & 1,3 & 0,21 & 1,08 \\
Kulit kopi rendam* & 10,55 & 2929 & 32,50 & 0,97 & 0,17 & 2,05 \\
Kulit kopi rebus* & 12,23 & 2764 & 20,60 & 1,28 & 0,26 & 0,88 \\
Jagung ** & 8,42 & 3182 & 2,15 & 5,17 & 0,22 & 0,6 \\
Dedak** & 12,9 & 2875 & 11,4 & 0,7 & 0,07 & 1,5 \\
Konsentrat*** & 38 & 2900 & 6 & 4 & 3 & 1,4 \\
\hline
\end{tabular}

Ket $: \mathrm{EM}=$ Energi Metabolisme, $\mathrm{SK}=$ Serat Kasar, $\mathrm{Ca}=$ Kalsium, $\mathrm{P}=$ Fosfor

*) Hasil Analisa Lab ilmu dan teknologi pakan IPB (2016)

**) Hasil Analisa Timbulus et al. (2017)

***) Hasil Analisa PT. Cargil Indonesia

Tabel 2.Susunan Bahan Penyusun Ransum Perlakuan

\begin{tabular}{lcccc}
\hline Bahan pakan & B0 & B1 & B2 & B3 \\
\hline Konsentrat & 30 & 30 & 30 & 30 \\
Dedak & 29 & 29 & 29 & 29 \\
Jagung & 40 & 30 & 20 & 10 \\
Kulit kopi(A1/A2/A3) & 0 & 10 & 20 & 30 \\
Mineral & 1 & 1 & 1 & 1 \\
\hline Total & 100 & 100 & 100 & 100 \\
\hline
\end{tabular}

Tabel 3. Komposisi Zat Nutrien Ransum Perlakuan

\begin{tabular}{cccccccc}
\hline \multirow{2}{*}{$\begin{array}{c}\text { Faktor } \\
\text { A }\end{array}$} & Faktor B & $\begin{array}{c}\text { Protein } \\
(\%)\end{array}$ & $\begin{array}{c}\text { EM } \\
(\mathrm{kcal})\end{array}$ & $\begin{array}{c}\text { Serat } \\
\text { kasar(\%) }\end{array}$ & $\begin{array}{c}\text { Lemak } \\
(\%)\end{array}$ & $\begin{array}{c}\text { Kalsium } \\
(\%)\end{array}$ & $\begin{array}{c}\text { Fosfor } \\
(\%)\end{array}$ \\
\hline \multirow{4}{*}{ A1 } & B0 & 18,50 & 2976,55 & 5,96 & 3,47 & 1,00 & 1,09 \\
& B1 & 18,46 & 2947,85 & 9,11 & 3,08 & 0,19 & 1,14 \\
& B2 & 18,41 & 2919,15 & 12,25 & 2,69 & 1,00 & 1,19 \\
& B3 & 18,36 & 2890,45 & 15,40 & 2,31 & 1,00 & 1,23 \\
& B0 & 18,50 & 2976,55 & 5,96 & 3,47 & 1,00 & 1,09 \\
A2 & B1 & 18,72 & 2951,25 & 9,00 & 3,05 & 1,00 & 1,24 \\
& B2 & 18,93 & 2925,95 & 12,03 & 3,14 & 0,99 & 1,38 \\
& B3 & 19,99 & 2900,65 & 15,07 & 2,21 & 0,99 & 1,12 \\
& B0 & 18,50 & 2976,55 & 5,96 & 3,47 & 1,00 & 1,09 \\
A3 & B1 & 18,89 & 2934,75 & 8,02 & 3,59 & 1,01 & 1,12 \\
& B2 & 19,27 & 2892,95 & 9,65 & 2,69 & 1,01 & 1,15 \\
& B3 & 19,65 & 2851,15 & 11,50 & 2,00 & 1,02 & 1,17 \\
\hline
\end{tabular}

Keterangan: Dihitung berdasarkan Tabel 1 dan 2

Faktor A terdiri dari A1= kulit kopi jemur, A2= kulit kopi rendam, A3= kulit kopi rebus Faktor $\mathrm{B}$ terdiri dari $\mathrm{B} 0=0 \%$ ransum kontrol (tanpa kulit kopi), B1= substitusi $25 \%$ kulit kopi terhadap jagung, B2= substitusi 50\% kulit kopi terhadap jagung, B3= substitusi 75\% Kulit kopi terhadap jagung. 
pemotongan kemudian dilakukan penimbangan bobot badan akhir secara bergilir, Pemotongan ternak dilakukan berdasarkan cara USDA (United State Departement of Agriculture, 1997), yaitu dengan memotong Vena jugularis, dan Artericarotis yang terletak antara tulang kepala dengan ruas tulang leher pertama. Setelah itu ayam digantung dengan posisi kaki berada diatas, kepala dibawah kemudian ayam segera dicelupkan kedalam air hangat dengan suhu $50-55^{\circ} \mathrm{Cselama} 90$ 120 detik untuk memudahkan pencabutan bulu. Sedangkan pengukuran bobot lemak abdomen dilakukan dengan cara menimbang lemak yang didapat dari lemak didalam tubuh ayam yang berada pada sekeliling gizzard dan lapisan yang menempel antara otot abdomen sertausus dan selanjutnya ditimbang.

\section{Variabel}

Variabel yang diamati ialah bobot badan akhir, Persentase karkas, Bobot Lemak Abdomen.

\section{HASIL DAN PEMBAHASAN}

Pengaruh perlakuan terhadap bobot badan akhir, persentase karkas dan bobot lemak abdomen dapat dilihat pada Tabel 4.

\section{Pengaruh Perlakuan Terhadap Bobot Badan Akhir}

Hasil analisis keragaman (anova) menunjukan bahwa interaksi antara kulit kopi yang dijemur, rendam, rebus dan level substitusi memberikan pengaruh tidak berbeda nyata $(\mathrm{P}>0,05)$ terhadap bobot badan akhir. Hasil yang sama juga ditunjukan oleh metode pengolahan kulit kopi yang artinya jemur, rendam, rebus memberikan pengaruh yang tidak berbeda nyata $(\mathrm{P}>0,05)$ terhadap bobot badan akhir. Sedangkan hasil yang berbeda ditunjukan level substitusi memberikan pengaruh berbeda sangat nyata $(\mathrm{P}<0.01)$ terhadap bobot badan akhir. Berdasarkan uji beda nyata jujur level substitusi menunjukkan bahwa ransum kontrol B0 berbeda sangat nyata $(\mathrm{P}<0.01)$ dengan $\mathrm{B} 2$ dan $\mathrm{B} 3$ serta tidak berbeda nyata $(\mathrm{P}>0,05)$ dengan $\mathrm{B} 1$. Kulit kopi level substitusi B1 berbeda sangat nyata $(\mathrm{P}<0,01)$ dengan $\mathrm{B} 3$ dan $\mathrm{B} 2$ serta level substitusi B2 tidak berbeda nyata $(\mathrm{P}>0,05)$ dengan B3.Hal ini menunjukan bahwa pemberian kulit kopi dengan level substitusi 25\% (B1) dan 0\% (B0) memiliki hasil tidak jauh berbeda dikarenakan rendahnya kandungan kulit kopi pada level substitusi $25 \%$ dalam ransum untuk menggantikan jagung. Rendahnya kandungan kulit kopi memberikan pertambahan bobot badan yang baik pada level substitusi 25\% (B1) dibandingkan level substitusi 50\% (B2) dan 75\% (B3). Kandungan kulit kopi yang tinggi pada level substitusi 50\% (B2) dan 75\% (B3) 
mengakibatkan rendahnya pertambahan bobot badan akhir. Semakin tinggi level substitusi kulit kopi maka semakin rendah konsumsi ransum, sehingga pertambahan bobot badan akhir menjadi lambat (Uzer et al., 2013). Tingginya kandungan serat kasar pada kulit kopi disebabkan adanya zat penyusun tanaman yaitu selulosa, hemiselulosa dan lignin, keberadaan ketiga zat penyusun tanaman dapatmenghambat $\mathrm{p}$ pencernaan pada ayam proses (Tillman $e t$ al., 1989). Ini didukung pernyataan

Tabel 4. Rataan Bobot Badan Akhir, Persentase Karkas, Bobot Lemak Abdomen.

\begin{tabular}{|c|c|c|c|c|c|}
\hline \multirow{2}{*}{ Variabel } & \multirow{2}{*}{$\begin{array}{c}\text { Level } \\
\text { subtitusi }\end{array}$} & \multicolumn{3}{|c|}{ Perlakuan } & \multirow[b]{2}{*}{ Rerata } \\
\hline & & A1 & $\mathrm{A} 2$ & A3 & \\
\hline \multirow{4}{*}{$\begin{array}{l}\text { Bobot Badan } \\
\text { Akhir (g) }\end{array}$} & B0 & $\begin{array}{c}2233,33 \\
\pm 62,13\end{array}$ & $\begin{array}{c}2233,33 \\
\pm 62,13\end{array}$ & $\begin{array}{c}2233,33 \\
\pm 62,13\end{array}$ & $\begin{array}{c}2233,3^{\mathrm{a}} \\
\pm 0,00\end{array}$ \\
\hline & B1 & $\begin{array}{l}2007,33 \\
\pm 128,24\end{array}$ & $\begin{array}{l}1894,00 \\
\pm 171,00\end{array}$ & $\begin{array}{l}1768,67 \\
\pm 134,25\end{array}$ & $\begin{array}{l}1890,00 \\
\pm 23,15^{\mathrm{b}}\end{array}$ \\
\hline & B2 & $\begin{array}{l}1182,00 \\
\pm 117,80\end{array}$ & $\begin{array}{l}1325,67 \\
\pm 239,65\end{array}$ & $\begin{array}{l}1521,67 \\
\pm 298,40\end{array}$ & $\begin{array}{l}1343,11 \\
\pm 92,12^{\mathrm{ab}}\end{array}$ \\
\hline & B3 & $\begin{array}{c}1015,33 \\
\pm 32,75 \\
\end{array}$ & $\begin{array}{l}1314,00 \\
\pm 255,11\end{array}$ & $\begin{array}{c}1108,67 \\
\pm 88,64\end{array}$ & $\begin{array}{r}1146,00 \\
\pm 115,68^{\mathrm{c}}\end{array}$ \\
\hline Rerata & & $\begin{array}{l}1609,50 \\
\pm 45,45 \\
\end{array}$ & $\begin{array}{l}1691,67 \\
\pm 87,86 \\
\end{array}$ & $\begin{array}{l}1658,08 \\
\pm 105,97 \\
\end{array}$ & \\
\hline \multirow{4}{*}{$\begin{array}{l}\text { Persentase Karkas } \\
(\%)\end{array}$} & B0 & $\begin{array}{l}74,00 \\
\pm 1,06\end{array}$ & $\begin{array}{l}74,00 \\
\pm 1,06\end{array}$ & $\begin{array}{l}74,00 \\
\pm 1,06\end{array}$ & $\begin{array}{l}74,00^{\mathrm{a}} \\
\pm 0,00\end{array}$ \\
\hline & B1 & $\begin{array}{l}75,64 \\
\pm 1,47\end{array}$ & $\begin{array}{l}73,93 \\
\pm 1,27\end{array}$ & $\begin{array}{l}73,29 \\
\pm 1,27\end{array}$ & $\begin{array}{c}74,29 \\
\pm 0,12^{\mathrm{b}}\end{array}$ \\
\hline & B2 & $\begin{array}{l}69,28 \\
\pm 2,93\end{array}$ & $\begin{array}{l}72,80 \\
\pm 1,09\end{array}$ & $\begin{array}{l}69,62 \\
\pm 1,34\end{array}$ & $\begin{array}{l}70,56 \\
\pm 1,00^{\mathrm{c}}\end{array}$ \\
\hline & B3 & $\begin{array}{r}65,20 \\
\pm 1,45 \\
\end{array}$ & $\begin{array}{r}70,09 \\
\pm 2,53 \\
\end{array}$ & $\begin{array}{l}67,56 \\
\pm 4,42 \\
\end{array}$ & $\begin{array}{r}67,62 \\
\pm 1,50^{\mathrm{ab}} \\
\end{array}$ \\
\hline Rerata & & $\begin{array}{l}71,03 \\
\pm 0,82 \\
\end{array}$ & $\begin{array}{l}72,70 \\
\pm 0,70 \\
\end{array}$ & $\begin{array}{l}71,12 \\
\pm 1,61 \\
\end{array}$ & \\
\hline $\begin{array}{l}\text { Lemak Abdomen } \\
\text { (g) }\end{array}$ & $\begin{array}{l}\text { B0 } \\
\text { B1 } \\
\text { B2 } \\
\text { B3 } \\
\end{array}$ & $\begin{array}{c}15,00 \pm 4,00 \\
6,40 \pm 4,00 \\
1,14 \pm 0,01 \\
0,05 \pm 0,01 \\
\end{array}$ & $\begin{array}{c}15,00 \pm 4,00 \\
7,27 \pm 8,00 \\
1,15 \pm 0,01 \\
0,11 \pm 0,01\end{array}$ & $\begin{array}{c}15,00 \pm 4,00 \\
5,73 \pm 9,9 \\
1,11 \pm 0,01 \\
0,08 \pm 0,01\end{array}$ & $\begin{array}{c}15,00 \pm 0,00^{\mathrm{a}} \\
6,47 \pm 0,77^{\mathrm{b}} \\
1,13 \pm 0,02^{\mathrm{c}} \\
0,08 \pm 0,03^{\mathrm{c}}\end{array}$ \\
\hline Rerata & & $5,65 \pm 6,82$ & $5,88 \pm 6,85$ & $5,48 \pm 6,80$ & \\
\hline
\end{tabular}

Keterangan: superskrip huruf berbeda pada kolom yang sama menunjukkan berbeda sangat nyata $(\mathrm{P}<0,05),(\mathrm{P}<0,01)$. 
Amrullah (2003) bahwa unggas memiliki sistem perasa pada ujung lidahnya yang mendeteksi rasa, tekstur, dan bau dari makanan saat mengkonsumsi ransum. Kelemahan kulit kopi juga dipengaruhi oleh zat anti nutrisi yang terkandung didalamnya yakni tanin dan kafein (Murib, 2016). Kandungan tanin dapat memberikan tekanan pertumbuhan lambat sehingga berdampak kerugian pada pemeliharaan ayam pedaging (Cannas, 2008). Karena protein menjadi sukar dicerna enzim protease disebabkan tanin telah mengikatnya menjadi ikatan kompleks tanin.

\section{Pengaruh Perlakuan Terhadap Persentase Karkas}

Rataan persentase karkas dapat dilihat pada Tabel 4. Hasil analisis keragaman (anova) menunjukan bahwa interaksi antara kulit kopi jemur, rendam, rebus dan level substitusi memberikan pengaruh tidak berbeda nyata $(\mathrm{P}>0,05)$ terhadap persentase karkas. Hasil yang sama juga ditunjukan oleh metode pengolahan kulit kopi yang artinya jemur, rendam, rebus memberikan pengaruh yang tidak berbeda nyata $(\mathrm{P}>0,05)$ terhadap persentase karkas. Sedangkan hasil yang berbeda ditunjukan level substitusi memberikan pengaruh berbeda sangat nyata $(\mathrm{P}<0.01)$ terhadap persentase karkas. Ransum kulit kopi dengan level substitusi yangberbeda memberikan pengaruh pada persentase karkas, dapat dilihat dari uji beda nyata jujur level substitusi menunjukkan bahwa kulit kopi level substitusi 25\%, 50\% memberikan pengaruh tidak berbeda nyata $(\mathrm{P}>0,05)$ terhadap ransum kontrol tetapi berbeda nyata $(\mathrm{P}<0.01)$ pada kulit kopi $75 \%$ sedangkan untuk kulit kopi $25 \%$ berbeda nyata $(\mathrm{P}>0,05)$ dengan $75 \%$, tidak berbeda nyata $(\mathrm{P}>0.05)$ pada $50 \%$ dan kulit kopi level $50 \%$ tidak berbeda nyata ( $\mathrm{P}>0.05)$ pada $75 \%$. Rataan persentase karkas pada penelitian berkisar $65 \%-75 \%$. Kisaran ini sesuai dengan pendapat North dan Bell (1992) bahwa persentase karkas ayam pedaging bervariasi antara $65-75 \%$ dari bobot badan. Persentase karkas dipengaruhi oleh bobot badan akhir dan bobot karkas sedangkan bobot karkas juga dipengaruhi oleh bobot potong (Haroen, 2003). Semakin berat ayam pedaging yang dipotong semakin tinggi persentase karkas yang dihasilkan. Persentase karkas lebih rendah, diduga dipengaruhi oleh bobot potong (Haroen, 2003). Bobot karkas ayam yang tinggi menghasilkan bobot potong lebih besar, seperti yang diperlihatkan pada penelitian bahwa pemberian level substitusi $25 \%$ kulit kopi dengan bobot karkas $1517,67 \mathrm{~g} \quad$ - 1296,67g menghasilkan persentase karkas 75,64 \% - 70,14\% hasilnya tidak jauh berbeda dengan $0 \%$ (ransum kontrol) rataan bobot karkas 2233,33 g menghasilkan persentase karkas 
$74,00 \%$. Sedangkan level substitusi $50 \%$ dengan bobot karkas 1062,00 g - 820,23 g menghasilkan persentase karkas $72,80 \%$ $69,28 \%$ begitu juga level substitusi $75 \%$ dengan bobot karkas 925,33 g- 662,00g menghasilkan persentase karkas 70,09\% 69,20\%. Persentase karkas ayam pedaging tertinggi pada level substitusi $25 \%$ denganrataan $75,64 \%$ sedangkan terendah pada level $75 \%$ dengan rataan $65,20 \%$. Penurunan persentase karkas diakibatkan tingginya kandungan serat kasar sehingga memicu berkurangnya nilai gizi dan energj ransum. Serat kasar tinggi menyebabkan imbangan protein dan energi yang terserap tubuh menurun (Dharmawati dan Kirnadi 2012). Semakin tinggi level substitusi ransum semakin rendah persentase karkas yang dihasilkan.

\section{Pengaruh Perlakuan Terhadap Bobot Lemak Abdomen}

Hasil analisis keragaman (anova) menunjukan bahwa interaksi antara kulit kopi yang dijemur, rendam, rebus dan level substitusi memberikan pengaruh tidak berbeda nyata $(\mathrm{P}>0,05)$ terhadap bobot lemak abdomen. Hasil yang sama juga ditunjukan oleh metode pengolahan kulit kopi yang artinya jemur, rendam, rebus memberikan pengaruh yang tidak berbeda nyata $(\mathrm{P}>0,05)$ terhadap bobot lemak abdomen. Sedangkan hasil yang berbeda ditunjukan level substitusi memberikan pengaruh berbeda sangat nyata $(\mathrm{P}<0.01)$ terhadap bobot lemak abdomen, dapat dilihat juga dari uji beda nyata jujur level substitusi menunjukkan bahwa kulit kopi level substitusi B0 berbedanyata sangat nyata $(\mathrm{P}<0,01)$ dengan $\mathrm{B} 1, \mathrm{~B} 2$ dan $\mathrm{B} 3$, Sedangkan B2 tidak berbeda nyata $(\mathrm{P}>0,05)$ dengan B3.

Dari rataan bobot lemak abdomen dilihat pada Tabel 4 ayam pedaging berkisar $0,08 \mathrm{~g}-15,00 \mathrm{~g}$ penelitian ini lebih rendah dibandingkan dengan penelitian bobot lemak abdomen yang dinyatakan oleh Faizal (2006), rata-rata bobot lemak abdomen sebesar 11,45 g - 22,11 g Bobot lemak abdomen level substitusi 25\% (B1), $50 \%$ (B2) dan 75\% (B3) menghasilkan lemak abdomen lebih rendah dibandingkan dengan ransum kontrol 0\% (B0). Lemak abdomen terendah pada ransum kulit kopi level subtitusi $75 \%$. Penurunan bobot lemak abdomen diikuti banyaknya pemberian kulit kopi, semakin tinggi level substitusi kulit kopi semakin rendah lemak abdomen yang dihasilkan. Kinerja energi dalam ransum sebagai zat makanan yang sebenarnya diperlukan bagi pertumbuhan, malah diserap untuk mencerna serat kasar. Serat kasar pada ransum perlakuan ini mengakibatkan ayam pedaging tidak dapat menyimpan lemak dalam tubuh karena kehilangan banyak energi. Lemak abdomen yang rendah dapat mempengaruhi kualitas karkas dari ayam pedaging (Yuniastuti, 
2002). Ayam pedaging dengan ransum perlakuan serat kasar tinggi memiliki jumlah lemak abdomen lebih rendah dibandingkan dengan serat kasar rendah (Sharikhan et al., 2010).

\section{KESIMPULAN}

Dari hasil penelitian dapat disimpulkan bahwa penggunaan kulit kopi dapat menurunkan lemak abdomen dan meningkatkan persentase karkas ayam pedaging. Kulit kopi dapat menggantikan jagung dengan level terbaik pada $25 \%$ $75 \%$.

\section{DAFTAR PUSTAKA}

Amrullah, I.K. 2003. Nutrisi Ayam Petelur Seri Beternak Mandiri. Cetakan ke2 Penerbit Lembaga Satu Gunung Budi. Bogor.

Cannas, A. 2008. Tannins: Fascinating but Sometimes Dangerous Molecules. New York (US): Department of Animal Science, Cornell University

Dewi, H.R.K. 2007. Evaluasi Beberapa Ransum Komersial Terhadap Persentase Bobot Karkas, Lemak Abdomen, Dan Organ Dalam Ayam Broiler. Skripsi. Fakultas Peternakan Institut Pertanian, Bogor.

Dharmawati, S dan A.S. Kirnadi. 2012. Pengaruh penggunaan tepung daun alang-alang (imperatacylindrica,sp) dalam ransum terhadap kadar lemak, kolesterol karkas dan organ pencernaan itik alabio jantan. Jurnal Ziraa' ah 34(2):150-160.

Ensminger, M. E. 1980. Feed Nutrition Complete. The Ensminger Publishing Company. Clovis. California.

Haroen, U. 2003. Respon ayam broiler yang diberi tepung daun sengon (albizzia falcataria) dalam ransum terhadap pertumbuhan dan hasil karkas. Jurnal Ilmiah Ilmu-ilmu Peternakan 6(1): 34-41.

Ihsan, N. F. 2006. Persentase Bobot Karkas, Lemak Abdomen Dan Organ Dalam Ayam Broiler Dengan Pemberian Silase Ransum Komersial. Skripsi. Fakultas Peternakan Institut Pertanian Bogor.

Mahfudz. 2009. Karkas dan Lemak Abdominal Ayam Pedaging yang diberi Ampas Bir dalam Ransum. Prosiding Seminar Nasional Kebangkitan Peternakan. Pusat Penelitian dan Pengembangan Peternakan Bogor.

Murib, S., M. Najoan, B. Bagau dan I. M. Untu. 2016. Pengaruh substitusi dedak halus dengan tepung kulit kopi dalam pakan terhadap performa broiler. Jurnal Zootek 36(1):218-225.

North, M.O dan D.D. Bell. 1992. Commercial Chicken Production Manual. 2nd Ed. The Avi Publishing Co. Inc. Wesport, Conecticut, New York.

Sarikhan, M., H.A. Shahryar, B. Gholizadeh, M.H. Hosseinzadeh, B. Beheshti, dan A. Mahmoodnejad. 2010. Effects of insoluble fiber on growth performence, carcass traits and ileum morphological 
parameters on broiler chick males. Int J Agic Biol. 12(4):531-536.

Steel R. G. D. dan J. H. Torrie. 1980. Principles and Procedures of Statistics A Biometrical Approach. Second Edition. McGraw-Hill International Book Company. Tokyo. Page. 633.

Timbulus, C.M., P.R.R.I Montong, A. Dp. Mirah, S.E. Siswosubroto.2017. Penampilan produksi ternak babi grower yang menggunakan tepung kulit kopi sebagai bahan pengganti sebagian dedak halus pada pakan. Jurnal Zootek 37 (2): 242-251.

USDA. 1997. Poultry grading manual. Agriculture Hand Book No. 30 U.S Department of Agriculture dalam Jurnal Peternakan Tropika 4(1): 184-195.

Uzer, F., N. Iriyanti dan Roesdiyanto. 2013. Penggunaan pakan fungsional dalam ransum terhadap konsumsi pakan dan pertambahan bobot badan ayam broiler. J. Ilmiah Peternakan 1(1): 282-288.

Widyani, R.Rr., S. Prawirokusuma, Nasroedin, dan Zuprizal. 2001. Pengaruh peningkatan aras energi dan protein terhadap kinerja ayam pedaging. Buletin Peternakan 25 (3): 109-119.

Witantra. 2011. Pengaruh pemberian lisin dan metionin terhadap persentase karkas dan lemak abdominal pada ayam pedaging asal induk bibit muda dan induk bibit tua. Skripsi. Universitas Airlangga. Surabaya.

Yuniastuti, A., 2002. Efek pakan berserat pada ransum ayam terhadap kadar lemak dan kolestrol daging ayam broiler, Jurnal Ilmiah Sainteks 9(3):175-183 